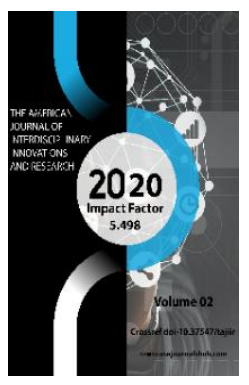

\title{
The Problem Of Young Personnel In The Development Of Science Of The Republic Of Uzbekistan
}

\author{
Topildiyev Odiljon Rakhimjonovich \\ (Phd) Associate Professor Of Namangan State University, Uzbekistan
}

Journal Website: http://usajournalshub.c om/index,php/tajiir

Copyright: Original content from this work may be used under the terms of the creative commons attributes 4.0 licence.

\section{ABSTRACT}

The article reveals that the Republic of Uzbekistan is systematically working to improve the quality and efficiency of the education system, the formation of modern knowledge and skills among young people, close cooperation between education systems and science, integration, continuity and continuity of education.

\section{KEYWORDS}

Education, training, system of education, quality of education, effectiveness of education, youth, modern knowledge, skills, system of education, science, sotrudnichestvo, integration, integrity and integrity of education.

\section{INTRODUCTION}

The growth rates of the socio-economic development of the Republic of Uzbekistan are highly appreciated by the world community. It is also the result of large-scale reforms aimed at developing science, reforming education, and comprehensive support for scientific and innovative activities. In the Republic of Uzbekistan, systematic work is being carried out to improve the quality and efficiency of the education system, the formation of modern knowledge and skills among young people, close cooperation, integration, integration and continuity of education between education systems and science. Today it is important to determine the priorities of the systemic reform of education and science in the Republic of Uzbekistan, to raise the process of training highly qualified 
personnel for independent thinking to a qualitatively new level.

\section{MATERIALS AND METHODS}

Today, it is necessary to take consistent measures to educate young people to be highly educated, physically and spiritually healthy, to increase the prestige of leaders and teachers of educational institutions, to create the necessary conditions for their effective work.

According to Decrees of the President of the Republic of Uzbekistan such as "On the longterm improvement of the system of preschool education in 2017-2021", July 28, 2017 and "On the increase of the effectiveness of spiritualeducational work and the development of development at a new level", September 13, 2017, "On a comprehensive measure for the development of the production and distribution system, enhancement and popularization of the culture of reading and reading", September 26, 2017, "On further development of the system of preparation of candidates for higher education", January 25, 2018, "On the radical improvement of the systems of secondary, secondary specialized and vocational education" on June 28, 2018, "On the awarding of the State Prize" on May 3, 2019 "On the development of talented young people and the organization of nonstop system of preparation of highly qualified personnel" on October 20, 2019, and Presidential Decree-5847 are directed to the accelerated development of reform in the field of education.

The upbringing of an educated and intelligent generation is clearly reflected in the democratic nature of state policy, and in the upbringing of the mature generation, these two concepts are always used in harmony with each other, they are the concept of education and upbringing. It is important that the process of teaching and upbringing of every person engaged in pedagogical activity becomes an everyday matter.

The concept of education is a didactic activity carried out by a teacher and students with the aim of ensuring the intellectual development of a person by increasing his spiritual, educational and educational level. This is a system of clearly defined measures aimed at ensuring the mental development of a person.

The concept of education is a social function that ensures the development of a new generation, giving the older generation a socio-historical experience, a purposeful, systematic conscious process of forming, making decisions, enriching and improving the personal and spiritual worldview of a person under social influence. It is an integral part of the education system, since it is the main link of socialization, which is intertwined with education.

\section{RESULTS AND DISCUSSIONS}

The new version of the Law of the Republic of Uzbekistan "On Education" provides for the following forms of education:

Separation from production (full-time);

$>$ Training is inseparable from production (correspondence, evening, correspondence);

$>$ Dual education;

Pamily education and self-study;

$>$ Adult learning and education;

$>$ Inclusive education;

$>$ External education; 
Training in defense, security and law enforcement.

Reforms in the field of education in the Republic of Uzbekistan began with the restoration of the preschool education system. The construction of modern, comfortable and well-maintained kindergartens has begun in each district. First, preschool educational institutions, which are the most important link in lifelong education, are being organized in a completely new form in terms of content and organization. This system will not only increase the coverage of preschool children with preschool education, but will also introduce learning mechanisms in individual groups, depending on their interests and the ability to communicate freely from 3-6 years old. As a result of reforms begun in the development of preschool education, 5722 state, private and family kindergartens were created in 2019. Thanks to this, the coverage of our children with preschool education has grown from $38 \%$ to $52 \%$ over the year.

By 2020, it is planned to increase the coverage of preschool children to $60 \%$. For the first time in our history, a system of preparing 6-year-old children for school has been introduced. There was practically no training for preschool teachers. A new era has begun in the quantity and quality of training for kindergarten teachers in higher educational institutions. The introduction of private forms of kindergartens and secondary schools into our life creates a healthy competitive environment in education. As a result, the choice of educational institution is introduced, as well as a new demand for innovative teachers and a corresponding salary system.
The return to 11-year schooling has further improved the quality of education and child rearing. This was the most important reform in education. Vocational education is also being revised. This system will be clear and optimal, based on the real needs of employers. In the vocational education system, the activities of colleges and technical schools are reaching a new level. The issue of training and paying for teachers has been resolved. A new vocational education system has been created. It is planned to increase the coverage of school graduates with higher education at least $25 \%$ by 2020 and $50-60 \%$ in the future. State grants for admission to higher educational institutions have been doubled, and special scholarships have been allocated to girls. The educational process in higher education in the academic year 20202021 was transferred to a credit-modular system, transferred to self-financing of higher educational institutions.

As a result, the future of our country, a new form of state policy for training national elite youth and a conceptual approach to education that will ensure the well-being of our people, will provide all sectors of our economy in the coming years with professionals with innovative thinking.

To achieve this goal, important factors for improving the quality and effectiveness of education have been identified, and a number of targeted measures are being taken to implement them throughout the country. The opening of private educational institutions that will create a competitive environment in the field of education based on the experience of developed countries, the study of foreign universities for young people to obtain 
innovative knowledge and science, and in 2019 they launched 4 Presidential schools and 3 schools of creativity. For the development of higher education, 19 new universities were opened in 2019, including branches of 9 prestigious foreign universities. In cooperation with leading foreign universities, training has been launched in 141 joint educational programs.

In this regard, President Sh. Mirziyoyev said: "No matter how difficult it is, we must admit that we must train talented youth abroad, in developed countries, in the most important areas for the development of our country. Therefore, the Ministry of Higher and Secondary Specialized Education, higher education institutions, research centers of the country should closely cooperate with the ElYurt Umidi Foundation. Of course, a bright future, prosperity and stability of our country, its worthy place among the countries of the world are in the hands of today's young people, who are undoubtedly innovative knowledge, in other words, the owner of human capital.

The quality of education is a priority of the state as a key and paramount factor in ensuring the development of society, and the training of national elites and the organization of their competitiveness in the world market is becoming a key issue in the regional strategy. The success of this important policy requires every citizen of the country to actively participate in education reform. Indeed, the quality of education depends not only on the qualifications of each teacher and his or her dedication to their profession, but also on the attitude of society towards education. Today, in parallel with training a new generation of teachers abroad or at home, we must develop a new, perfect and adaptable system for the professional development of teachers aged 25-45 who are currently working in higher education institutions. It should be noted that the teacher has always been a key figure in the education system. After all, the quality and effectiveness of teaching, the process of educating modern youth depends, firstly, on the profound knowledge and potential of the teacher, and secondly, on the teacher's professionalism, effective use of innovative pedagogical and information technologies, and thirdly, on his innovative approach to teaching and dedication to their profession. depends on his tireless work in capacity building and skills development.

In the center of the ongoing reforms in the Republic of Uzbekistan, the issue of training, identification, selection and systematic work with promising young specialists is certainly more relevant than ever. Based on the above, it is advisable to make the following proposals for training young specialists in the development of science and education:

- Development of a network of educational institutions for the training of young specialists on the basis of modern requirements and standards, their reconstruction and modernization;

- Sistematicheskaya rabota s molodymi kadrami, privlechenie $k$ nim kvalifitsirovannyx prepodavateley, ispolzovanie nauchno obosnovannyx, logicheski obosnovannyx didacticheskix materials i metodov ix primeneniya, sistemy uchebnyx sredstv, metod uvezovche formov; ispolzovanie form; 
- establishment of effective public control over the educational process in educational institutions;

- obespechenie prozrachnosti v organizatsii uchebnogo protsessa;

- Selection of grant funds for fundamental and innovative research in science and expansion of research management;

- introduction of information technologies in all stages of training, the completeness of the corresponding international standards;

- Development of competitive means in education on the basis of experience of development of the country.

\section{CONCLUSION}

In conclusion, thanks to the state policy towards youth in the development of science and education in the Republic of Uzbekistan, a solid foundation is laid for a new level of education, science and technology. On this basis, the quality and efficiency of education will radically change, the scientific and technical infrastructure of innovative science will be formed, thousands of young intellectuals will be trained in cooperation with foreign universities, which will increase the country's position in the world intellectual property market.

\section{REFERENCES}

1. Strategy of actions for the development of the Republic of Uzbekistan for 20172021. Collected Legislation of the Republic of Uzbekistan, 2017, N 6, Article 70.

2. Decree of the President of the Republic of Uzbekistan dated May 3, 2019 "On measures to identify talented youth and the organization of a continuous system for training highly qualified personnel" // People's speech, May 4, 2019.

3. Decree of the President of the Republic of Uzbekistan No. PF-5847 of October 8, 2019 "On approval of the Concept for the development of the higher education system of the Republic of Uzbekistan until 2030" // Narodnoe Slovo, October 9, 2019. 